\title{
Of Shoulders and Shadows: Selected Amish Scholarship before 1963
}

\author{
"If I have seen further, it is by standing on the shoulders of giants." \\ Isaac Newton (1643-1727) \\ "There is a strong shadow where there is much light." \\ Johann Wolfgang von Goethe (1749-1832)
}

\author{
Joseph Donnermeyer ${ }^{3}$ \\ Professor Emeritus \\ School of Environment and Natural Resources \\ The Ohio State University
}

\begin{abstract}
John Hostetler's first edition of Amish Society in 1963 is a milestone in the advancement of scholarship about the Amish. It was revised and re-issued through three more editions. Even though the fourth and final edition was released nearly a quarter century ago, in 1993, Amish Society remains the most frequently cited authoritative sources about the Amish. Yet, there was a wealth of other solid scholarly work about the Amish before 1963, by such notable authors as Elmer Lewis Smith, Calvin Bachman, Walter Kollmorgen, Charles Loomis, and William Schreiber. The purpose of this review essay is to re-consider the merits of their scholarship, to demonstrate why those interested in understanding the Amish and other plain Anabaptist groups today should re-discover what they had to say. This review essay can be read either in its entirety, or, if the reader is interested only in certain scholars, just within sub-sections, as they are written as stand-alone essays, with minimal cross-referencing.
\end{abstract}

\section{Keywords}

Elmer Lewis Smith; Calvin Bachman; Walter Kollmorgen; Charles Loomis; William Schreiber; John Hostetler; Theory; Amish studies; German studies; Community studies; Rural Life Studies; Culture of a Contemporary Rural Community; Rural sociology; Social system; Folklore; Demography; Bundling; Lancaster County, PA, Amish settlement; German peasant; Bauern

\section{Acknowledgements}

Acknowledgements are extended to Cory Anderson, the editor of this journal, for his useful suggestions in a number of places in this review essay, particularly about the heritage of Kollmorgen's research in the scholarship of others during the 1940s through 1960s and the value of Schreiber's peasant/Amish link as both a unique insight and as an observation worth keeping in mind by Amish scholars. 


\section{Introduction}

We may view John Hostetler as that famous "giant” of Amish scholarship on which all of us stand today, but indeed, a very strong case can be made that there is more than one giant from the past, as the quote from Newton and part of the title for this article asserts. Hostetler benefitted from the shoulders of others who wrote before and about the same time as the first edition of his now classic Amish Society (1963) was published. This is obvious when perusing the extensive reference list at the end of the original edition of his book. Without their scholarship, he could not have written Amish Society, whether he liked and agreed with what they said, or he did not. Yet, recent conferences and literatures associated with Amish studies seem to suggest that not much else existed of any worth before 1963. Perhaps the great influence of Hostetler's impressive scholarship had the unforeseen consequence of throwing a shadow over the scholarship of those others who were either contemporaries or predecessors to him. Hence, the quote from Goethe and the other half of this review essay's title.

Of course, a great deal of the shadow-casting of earlier work was inadvertent, given how much Hostetler wrote about the Amish and the high level of his scholarship. However, as so many scholars of Amish and plain Anabaptist studies already know but is nonetheless worth repeating: the shadow cast by Hostetler over Elmer Lewis Smith's scholarship, for example, was quite purposive, creating an undeservedly diminished legacy for Smith (Weaver-Zercher 2005a).

Hostetler himself pre-dates his 1963 tome with a variety of scholarly works in journals and other venues about the Amish (Weaver-Zercher 2005a). One notable contribution to early Amish scholarship is his 1951 Annotated Bibliography on the Amish. This is arguably the first attempt to capture the universe of literature about the Amish, which at that time was beginning to grow rapidly. Another is his easy to read booklet Amish Life, first published in 1952 by Herald Press and revised and re-published several times thereafter. This short, 32-page publication is like an "Amish 100" course for readers at the midway point of the twentieth century who sought out an authoritative introduction. In it, he reviews the essential characteristics of the Amish, emphasizing their diversity, factors that "keep them separate" (pp. 10-12) and "attachment to the soil” (p. 30), citing his predecessors, Walter Kollmorgen (1942) and Calvin Bachman (1942). ${ }^{4}$

The purpose of this review essay is to attenuate both the unintended and intended shadows of Hostetler by reviewing selected early forms of scholarship and to remind those interested in theory and research about the Amish and other plain Anabaptist groups that all did not begin in 1963. It is important for the scholars of tomorrow to understand that there was a rich diversity of scholarship back before that time, and that a diversity of scholarship about the Amish and other plain groups continues to grow today, extending beyond any one individual and any single university, center, institute, or academic department.

The remainder of this review essay is divided into six parts. The first deals with two publications by Elmer Lewis Smith. I highlight his scholarship first because of the well-known 
objections of Hostetler to Smith’s work and the way, in my opinion, Lewis’ work has been unjustifiably ignored by many scholars of the Amish today. By reviewing what Smith actually said, a new understanding of an old controversy can be attained. The next four parts consider the work of several other early scholars, including Calvin Bachman, Walter Kollmorgen, Charles Loomis, and William Schreiber. All have relevance for the future of Amish scholarship, both theoretically and empirically, in this $21^{\text {st }}$ century. Finally, a short summary of the pre-1963 scholarship reviewed in this essay considers lessons learned for the future development of scholarship related to the Amish and other plain Anabaptist groups.

The reader is advised that each review can be read as a self-standing examination of these early classics, even though there is some cross-referencing to the work of others also reviewed here.

\section{The Nearly Forgotten Scholar: Elmer Lewis Smith (1920-1981)}

Both Simon Bronner's (2005) and David Weaver-Zercher's (2005a) chapters in Writing the Amish: The Words of John Hostetler (Weaver-Zercher 2005b) document Hostetler's "campaign" against the perceived dislikes of the Amish scholarship of Elmer Lewis Smith (and others, too), especially concerning Smith's treatment of issues like bundling and sex. Both chapters note that Hostetler considered himself an insider, whilst Hostetler considered Smith an outsider. This campaign against Smith appears quite contentious, at least in the way I interpret the Hostetler's quotes in Weaver-Zercher (2005a), for example, a “pointed letter” to Smith in which "Hostetler believed that Smith-like portrayals of the Amish, which emphasized moral failings and libidinal oddities, did a terrible disservice” (p. 121).

As this review of two of Smith' works $(1960 ; 1961 \mathrm{a})$ will note, from a $21^{\text {st }}$ century point of view, Hostetler's objections seem to be closer to a Shakespearian play titled "Much Ado About Nothing." Perhaps that is because I write this essay at a time when the multiplicity of wretched reality shows, shallow romance novels, various sensationalistic media stories, and grossly inaccurate web-page depictions of the Amish are voluminous. Even some publications cited at scholarly conferences about the Amish veer toward strange topics or make a big deal out of highly unusual incidents that provide creative fodder for more articles, books, and other publications. Regardless, this review serves as a de facto defense of Smith, as both chapters of Weaver-Zercher's (2005b) edited book that dealt with the controversy presented only Hostetler's objections, not what Smith actually found or how he said it. This is not meant as a criticism because Weaver-Zercher's (2005b) homage to Hostetler was intended to focus on Hostetler's work, life, and defense of the Amish.

Smith himself grew up in Newark, New Jersey and earned an M.A. at Western Reserve University (now, Case Western Reserve University in Cleveland, Ohio) and a doctorate from Syracuse University. He was a sociologist who became interested in folk societies of various kinds. A special collection of his work is at James Madison University’s Carrier Library. It states 
that he was a founder of the Shenandoah Valley Folklore Society. The web source also indicates that he published in "a wide variety of books and papers, many of which are available at the Blue Ridge Institute in Ferrum, Virgina" (Guide to the Elmer Lewis Smith Collection, accessed October 14, 2016).

I contend that it is time to bring the work of Elmer Lewis Smith back to the forefront of scholarship! In fact, it can be argued that in the future, his work will be featured more and more because of the groundbreaking scholarship he accomplished in his demographic analyses and in his careful interpretation of both quantitative and qualitative data in order to couch his conclusions in carefully worded summaries. Few fancy alliterations, metaphors or similes characterize the titles of Smith's publication or the scholarship within.

Why do I say Smith's nearly forgotten scholarship has a brighter future? There is now a small group of scholars who go by the acronym APRG (Amish Population Research Group), of which I am a member. Smith's ability to access demographic data about the Amish and to carefully analyze it at a time when computers and statistical software packages did not exist is remarkable. Yet, he also extensively collected evidence through a qualitative approachconversations, interviews, correspondences, etc. I have no doubt that members of APRG will copiously cite and enthusiastically emulate Smith's scholarship, and through us, so too others will come to recognize his scholarship someday. By doing so, we will stand as much on Smith's shoulders as on anyone else's. Speaking for the others, I believe the members of APRG prefer greatly shoulders over shadows. A review of two of Smith's many publications about the Amish-"Studies in Amish Demography" and The Amish Today-will demonstrate the confidence of my prediction. ${ }^{5}$

\section{Smith’s “Studies in Amish Demography”}

This work was published by The Research Council of Eastern Mennonite College in 1960. The style of writing in the first two-thirds of this report is incredibly terse, even to the point of describing it as ambushing the reader with conclusions that forces one to re-read the passage and search for the correct statistic in the many tables scattered throughout. In fact, Smith (1960, p. iii) describes "Studies in Amish Demography" as a "series of reports" and starts with the declaration that "Much has been written about this interesting sect. At the same time, relatively little specific factual information has been available.” The forward includes an endorsement of Grant Stoltzfus of the Research Council, who declares that “... Studies in Amish Demography should illuminate many obscure phases of Amish culture and correct prevalent misunderstandings of a centuries-old way of life."

One thing this study is not short on is statistical information. These statistics are based on an examination of marriage licenses in Lancaster County, PA. Smith searched for those who were Amish; 580 were identified over the 15 -year period of records scrutinized. A second study by 
Smith of marriages based on Amish genealogies from families in southeastern Pennsylvania spanning a 66-year period (1890-1956) included over 1,200 cases.

Smith observes that nearly three-fourths of marriages occur in November, with most of the rest in either October or December. Lewis also notes that about 4.1 percent of Amish marriages had a child within eight months of the wedding. Later on in this publication, he observes that the rate of pre-marital pregnancy has fluctuated only slightly over this same period of two-thirds of a century. I suspect this might be one of those libidinous considerations of which Hostetler objected, yet, anyone who reads Smith's report will note the care with which he interpreted his statistical findings and the indirectness of his language. For example, he referred to marriages in which a child was likely conceived pre-maritally and the need to wed out of season as "expediency due to some embarrassing condition" (p. 4). By $21^{\text {st }}$ century standards, Hostetler's objections to Smith seem quite miniscule, even though everyone who writes about Hostetler as a scholar and as a person recognizes the sincerity of his effort to fight back against unfounded public images of the Amish (Weaver-Zercher 2005a). ${ }^{6}$ The unfortunate consequence of this zeal, however, is that one great scholar is remembered and the other mostly is not.

Smith notes that even though one would expect a rural-located group who depends on agriculture to marry earlier than the general population, his statistics say otherwise. Little change in age of marriage amongst the Amish occurred since 1890. Hence, no evidence exists that age of marriage is postponed due to shifts out of agriculture up to that time. He also notes that Amish males do marry a half-year younger than the general male population, despite the increasing difficulty of finding suitable farm land. The assumption is that a young man would not marry until he is set up on his own farm, which pushes back the age of marriage.

Smith has many other statistical findings. The percent of childless couples has not increased. Family size is larger than the general population and has not declined. "If one were asked to characterize the major Amish values in four words," he says, "those four words would be: Faith, Family, Farming and Fellowship” (p. 20).

Remarriage is far more frequent among males than females, as many widowers often marry younger Amish women who had never been married but generally past the usual age for marriage. Smith also explores through his statistical analysis marriages between individuals from different settlements (noting very little), the relatively few number of different surnames, child naming practices (given names and middle names), and nicknames.

Smith then turns his demographic lens to deaths. He concludes that, contrariwise to outsider images of high Amish stillbirths and infant death rates, both rates have declined over time, then comparable to the relatively low rates of urban people. As well, Smith considers the age and sex composition of the Amish population, and presents several tables for the general population in comparison. 
The language in Parts I and II is very dry, befitting a discussion of statistics. The tone changes with Part III, which considers the "The Amish Family Cycle.” It is in this section that he discusses bundling. Smith says things that make the size of Hostetler's negativity to appear lilliputian when re-read today. For example, Smith makes statements like: (1) "The Amish people of Lancaster county area consider it an insult to be associated with the practice of bundling” (p. 70); (2) that in regard to bundling "the evidence is always hearsay and indirect” (p. 77); and (3) "Not one Amish settlement has been singled out where the practice exists, and individual case material is completely lacking” (p. 80). These statements show the care with which Smith deals with evidence (whether qualitative or quantitative) to verify claims. Curiously, Smith cites page 76 of Hostetler's (1952) Amish Life, which states that bundling is still practiced, even if only in a few settlements. Perhaps what now seems like an exaggerated and largely one-sided brouhaha can be understood within the context of the time in which Hostetler mounted his so-called campaign (Weaver-Zercher 2005a) and when Smith published his 1961b booklet exclusively devoted to bundling from a folklorist point of view. ${ }^{7}$ By then, the Kinseys' reports on the sexual behavior of males and females were published. Both were the subject of considerable controversy and form the context in which sensitivities about libidinous topics were addressed in those days.

The remainder of "Studies in Amish Demography” returns to a more statistical style in its narrative, examining age of marriage, differences in the age of brides and grooms, the perpetuation of farming, the location of newlyweds, the age of parents at the birth of their first child and last child, and various other facts common to a thorough demographic analysis of any population.

\section{Smith's The Amish Today}

Smith published his first sizeable Amish book in 1958, The Amish People: SeventeenthCentury Tradition in Modern America. In 1960, the Pennsylvania German Folklore Society published Smith's second major book, The Amish Today: An Analysis of Their Beliefs, Behavior and Contemporary Problems as volume 24 of the Society's annual “Yearbooks" (p. vi), then published in book form the next year (Smith 1961a). It includes photographs by Melvin Horst, who collaborated with Smith on many other folklore-related books. At the time, Grant Stoltzfus - who wrote the introduction for "Studies in Amish Demography" — was a member of the board of the Pennsylvania German Folklore Society.

The introduction is a bibliography in narrative form. Smith conscientiously mentions many pamphlets and books, research theses, dissertations, journal articles, and literary accounts in respected magazines (such as Atlantic Monthly), concluding that "By far the greatest amount of writing has been done in the past two decades, despite the fact that the Amish have been in this country almost 250 years” (p. 1). He does, in my opinion, make the mistake of calling them “A Living Museum” but then I am interpreting his book and words nearly 70 years later. 
Smith intersperses quotes, anecdotes, and case study information that social scientists today would describe as qualitative, with his penchant for using demographic or quantitative data whenever possible. No other Amish scholar, past or present, has exhibited such an ability to synthesize or blend two different kinds of information in a similar manner. For example, in Chapter 1, he describes a conversation with an Amishman, seeking directions to another Amish home (p. 19). It is both a humorous anecdote and an effective way to show the cohesive or Gemeinschaft nature of the Amish. By contrast, in Chapter 2, 36 passages in 14 pages present numerical information about the Amish and other plain groups in Lancaster County.

Chapters 1 and 2, with their considerable detail, lay the groundwork for the remainder of the book. In the first half of Chapter 3 (which begins Part II), Smith presents a brief history of the Amish and then discusses various practices of the Amish in relation to Bible passages. This is another case of Smith as a careful researcher being wrongly criticized by Hostetler, who believed that as an insider-Hostetler's “my people” and Hostetler's depiction of Smith as an “outgrouper” (Bronner 2005, 65)_anyone like Smith who attempts to fit Amish practices to Bible passages was incorrect. "For Hostetler, the significant guiding principle for the Amish was their reliance on tradition to perform the social function of holding the community together" (Bronner 2005, 65). Yet, as I shall address later, both Bachman and Schreiber do much the same, and furthermore, their narratives are stylistically similar to Smith. My interpretation is that Smith was doing what any scholar, regardless of that scholar's religious background, who studies the Amish and other plain groups should do: find the links between practice and belief and inform the reader of these connections. In this case, the Bible is quite pertinent to the Amish church and of the normative structure of Amish communities, as Smith recognized: "Today, as in the distant past, the church remains as the major institution holding the various Amish families together, and it is the common religion that gives the group its social cohesion and solidarity” (p. 42).

The second half of Chapter 3 is a very interesting narrative on excommunication and shunning. Smith's intent is simple: "Stories have been told of how the Amish never again speak or look at an excommunicated former member. Actually, they show the guilty person every possible kindness, but treat him as if he is an outsider” (p. 55). Smith's discourse on this subject includes several cases studies and other pieces of evidence from key informant interviews. Chapter 4 (mislabeled as Chapter 5) is about the church leadership, the church service, the wedding, and other ceremonies. This chapter concludes Part II.

Part III has a single theme: the Amish family. In a sense, this is the heart of the book and core of Smith's style, deftly combining statistical information from his various research studies with qualitative data gathered through his long-term fieldwork in the Lancaster County settlement. Again, he deals with bundling in Chapter 5 (Dating and Courtship), arriving at what in my opinion is a sound, scientific conclusion for the time: “...the development of a method by which documentary evidence was obtained from other young people who had knowledge of the practice... at least some Amish young people in some settlements in Ohio, Indiana, Illinois, Kansas, and Pennsylvania still bundle, although in Tennessee and Virginia they do not” (p. 89). 
One wonders how good social science like this could have been so contentious with Hostetler, even back then.

Only a few pages later, after considering his own statistics in a section titled "Is Sex a Problem?” Smith concludes: "The low Amish pre-marital pregnancy rate is one evidence that rumors of extensive pre-marital sex looseness among the Amish are exaggerated or unfounded" (p. 92). As well, Smith deals with the "Blue Gate Legend”- a home's blue gate advertises a daughter of marriageable age_-by applying data. To quote: "Over ten years this writer travelled over every road and lane in the so-called 'Amish section' [of Lancaster County]...he found only one fence gate painted blue...” (p. 95), and that home was not Amish. The remainder of Chapter 5 and all of Chapter 6 (The Wedding and Marriage) are straightforward descriptions of these practices.

Chapters 7 and 8 concern the Amish roles of husband and wife, respectively, and are very descriptive in nature, with Smith intermixing a few statistical facts with occasional quotes and anecdotes. This style, which seems befitting of someone who comes at the subject matter as a folklorist, continues through the remainder of Part III, which progresses from "The Amish Home” (Chapter 9), "Parenthood” (10), and "The Children” (11) through "Recreation of the Family” (12), “Grandparenthood” (13), and "Sickness and Death” (14). Whenever he is able, he applies statistical data, most evident in Chapter 10 about parenthood. Smith provides the reader with statistics on homebirths, average age of motherhood and fatherhood, family size, child spacing, age of parents at birth of last child, and percent of childless families.

In each chapter of Part III, Smith uses incidents to illustrate the strength and cohesion of the Amish or to dispel unfounded images. For example, Chapter 11 includes a story about the Amish role in closing a tavern in the village of Intercourse that served alcohol to young, unmarried Amish males. In Chapter 12, Smith describes a wide variety of recreational activities, noting that dancing was not the taboo other writers had supposed and that, contrary to a short story published in a widely read American magazine called Scribner's, dolls are not uncommon toys for Amish girls. Chapter 13 examines the age of parents when their last child is married, the number of grandchildren, and concludes with a description of the Grossdaadi house. Chapter 14 addresses reduction in the rates of stillborn babies and infant deaths, and even considers the issue of suicide, describing briefly the circumstances of cases based on records. Smith sticks to an evidence-based approach even on the issue of burial of Amish who committed suicide by observing that “... a check of some of the cases referred to indicated they were interred next to other members of their families” (p. 191). This chapter is also an amazing description of the rituals and traditions surrounding death, funeral services, and burials. In folklorist style, he reproduces examples of obituary poems and concludes, "In the writer's opinion, Amish obituary and memorial poetry has been almost completely overlooked as folk literature” (p. 206). 
Part IV is titled "Contemporary Problems," the theme of which seems to be to one of describing a common image of the Amish from the outside and then applying both quantitative and qualitative evidence to dispel them, partly or completely, as mere stereotypes and falsities.

Chapter 15, “The One-Room School Philosophy,” is a very interesting pre-Yoder description of the conflicting interests between Amish and the state. He lays out the Amish preference for "ungraded one-room schools"; opposition to consolidated schools, electricity, and other conveniences in school buildings; and a modern public school curriculum that is no longer in line with a vocationally oriented education. In a straightforward manner, Smith includes a section titled “Are the Amish Ignorant?” (pp. 214-17). His verdict—no—but indeed, they do not “...share some of our interests and concerns” (p. 216).

A focus on education continues in Chapter 16, "The School Controversy.” Smith recounts incidents of Amish opposition to school laws and court cases in Pennsylvania beginning in the 1930s. He lays out Amish objections to the ever-changing school system and educational philosophies of mainstream America. It is an excellent historical record, in my opinion. Smith concludes Chapter 16 by observing:

One lasting result of this conflict has been the widespread public opinion that the Amish are uneducated, ignorant and stubborn...In all, the controversy has created a wide gap between the sect and the rest of the community, and some hard feelings exist. (p. 250)

Chapters 17 and 18 address farming. Chapter 17 is mostly a description of farming in Lancaster County but does discuss issues through various anecdotes and quotes about the desire of some Amish farmers to modernize agricultural practices, such as the use of machinery. Perhaps the best part of this chapter is Smith's narrative on "The Tobacco Paradox" (p. 267). He approaches the topic by describing tobacco as "a family crop" and concludes in a very nonjudgmental manner that the:

...tobacco crop is functional both in relation to financial necessity and to family enterprise. [...] Almost all family members, young and old alike, participate, with a great amount of the work coming during the quiet winter months and thereby presenting chores for all the children at a time when other farm activities are at a minimum. (p. 267)

Given my own views on tobacco, from a personal point of view I find this passage to be both insightful and unsatisfactory. I wish he had considered a tobacco-less future for these farm families, contextualized within the economic, social, and cultural parameters of Amish society during the mid-twentieth century.

Chapter 18 continues Smith's style of presenting an issue, discussing it, and reaching a conclusion. For example, he addresses with an array of statistics the issue of land and population pressure in Lancaster County. After considering alternative solutions-buying up the limited number of non-Amish farms, reducing high birth rates, and migrating to establish new settlements-Smith arrives at a fourth solution foreshadowing Amish occupational 
diversification. To quote: “...the Amish could still maintain a rural tradition without all of the members occupied as farmers” (p. 275). He then mentions a wide variety of non-farm occupations that are, in fact, what most Amish men do today. Smith goes on in this chapter to mention other issues, including the problem of maintaining contracts with non-Amish dairy companies and the subsequent establishment of Amish-owned cheese and milk cooperatives.

In Chapter 19, “The Amish and Government," Smith immediately dives into the issue of "selective service" and highlights the inability of the general public to understand the Amish view of war. As a result, “...plain people have experienced unpleasant comments and incidents instigated by the non-Amish who have not appreciated their attitude during periods of national crises and stress."8 This chapter also includes narratives on highway accidents, licenses for buggies, objections to social security, government actions taken against the Amish, and voting in elections. Throughout this chapter, Smith cites local and national news articles extensively.

In Chapter 20, Smith shifts emphasis to Amish businesses, highlighting carriage-making, harness-making, furniture / cabinet-making, other non-farm businesses, and Amish women's home-based businesses. One interesting narrative is the description of the Smoker Farm Elevator (later bought out by New Holland), founded on the inventiveness of an Amishman who subsequently established a factory with 30 employees. However, at the time, the use of electricity in the factory and the presence of a telephone were controversial, the result of which was that some employees joined more progressive “Church Amish” groups rather than work elsewhere.

Chapter 21 discusses "Urbanization and Suburbanization” and Chapter 22 addresses "Public Hostility toward the Amish.” Both chapters treat the Amish as having never lived as an isolated group. External influences have always been and continue to be powerful sources of change, and that these changes should not automatically be viewed as negative. For example, Smith includes a section in Chapter 21 titled “Advantages of Population Congestion” where he talks about the advantages of farming (especially dairy) in Lancaster County in relation to nearby population centers-Philadelphia to Baltimore, northern New Jersey and the New York metropolitan area. He also mentions the dollars tourists bring to the Amish through their roadside markets and of Amish who have "tended markets" (p. 317) at distant urban localities along the East Coast.

Chapter 22 begins with a description of various types of outsider views of the Amish, including: (1) positive views by those who know little except for what they read in a magazine or news story; (2) those who romanticize the Amish as an escape from the pressures of contemporary urban living; (3) non-Amish who live near the Amish and who appreciate the strong religious basis of their lifestyles; (4) those who live near the Amish but who see "...the sect as a means to promote their own welfare” (p. 319) as with gift shop and restaurant owners; and (5) those who hold negative views that “...seem to range from overt hostility to disgust and general annoyance” (p. 319). This chapter includes sections on how the Amish presence influences non-Amish owned businesses and public services, of hostile stories/myths about the 
Amish, and of crimes committed against the Amish. Each of these topics is equally relevant to the Amish in the $21^{\text {st }}$ century and forms the basis for a comparison of Amish relations to locals and outsiders any place where a new settlement has been founded today.

The final chapter (Chapter 23) seems completely out of place, because it is about "Amish Leadership.” Anyone who reads this chapter will question why it is in a section titled Contemporary Problems. Worst still, Smith provides no conclusion or summary of this book, and of themes and major conclusions he might have reached from the vast array of topics he addressed and the incredible diversity of qualitative and quantitative evidence he used throughout. ${ }^{9}$ Puzzling indeed, and even though it detracts from the over-all quality of The Amish Today, it should no longer be under the shadow of Hostetler's campaign against Smith's scholarship.

The bottom line: The Amish Today is a book that any new scholar to the study of the Amish and other plain Anabaptist groups should read, as a companion piece of equal quality and informativeness as Hostetler's Amish Society. And beyond this one book, Smith's aggregate work represents a milestone of empirically grounded mid-century Amish research that, for historiccomparative considerations should not be ignored. Smith's rejection of scholarly-level romanticism or protectionism toward the Amish allowed him to approach the Amish with great neutrality, and the result was that he foresaw some trends that Hostetler did not, as with occupational shifts

\section{The Sympathetic View: The Work of Calvin George Bachman (1892-1968)}

Bachman's book, The Old Order Amish of Lancaster County, was first published in the proceedings of the Pennsylvania German Society in $1942^{10}$ and republished in 1961 . Hostetler was a member of the Board of Directors by 1961 and wrote an introduction for its republication. Hostetler proclaimed: “The Methodology of this book is sound” (p. iii), and also described it as “...the first complete, sympathetic and authoritative ethnography of a community of Old Order Amish in America” (p. iii, emphasis added). What makes this particular quotation so interesting is that Hostetler's so-called successor-Donald Kraybill—wrote with his colleagues the very same claim about Hostetler's (1963) Amish Society: "His groundbreaking work was the first comprehensive scholarly treatment of Amish life [...]” (Kraybill, Johnson-Weiner, and Nolt 2013, xi, emphasis added). More shadows! All are wrong!

The date for re-issuance of Bachman's book cannot have been a coincidence. It is a purposive response to Smith's publication through the Pennsylvania German Folklore Society. As Weaver-Zercher (2005a) observed: “...Hostetler often used tactics that were less academic than political [including] behind the scenes maneuvering” (p. 121). The Folklore Society itself can be viewed as a partial spin-off of the Pennsylvania German Society. It was founded in 1935 in part because of the declining membership of the Pennsylvania German Society, which required proof of German ancestry from the seventeenth and eighteenth centuries for 
membership (i.e. another variant of the insider-outsider dichotomy). The Pennsylvania German Folklore Society attempted to provide an organization for those with common interests in the arts, music, literature, and other influences of Germans to the cultural and social development of Pennsylvania, and it did not require German ancestry for membership. In other words, outsiders or "outgroupers" could join. Many individuals belonged to both organizations, and, subsequently, in 1965, the two organizations merged because by then, both were affected by declining membership. Curiously, they adopted the name The Pennsylvania German Society, hence, the capitalization of the " $\mathrm{T}$ ” resulting, technically speaking, in adding a new word to an older moniker (Pennsylvania German Society, accessed 10/3/2016).

Yet, despite Hostetler's use of Bachman's book as a pawn for what appears to be part of his campaign against Smith, The Old Order Amish of Lancaster County should be read for its own worth, as a contemporary to the next classic to be reviewed, which was written by Walter Kollmorgen. When placed back into a non-"office politics” context, the Bachman book can be more clearly interpreted as a good piece of scholarship based on what he observed during his 25 years as pastor of a church in New Holland, Pennsylvania (plus, like Smith’s book, many excellent photographs, this time by Charles S. Rice). Of special significance is that this is indeed a comprehensive description of the Amish based on Bachman's observations through the 1920s and 1930s.

The first 60 pages of Bachman's book is a detailed account of Anabaptism in Europe, from the Peasants' War and the events in Zurich to the Schleitheim Articles of 1527 and the events surrounding Muenster in the 1530s. His second chapter (the chapters are actually unnumbered) is an excellent account of Menno Simons and his rise to leadership of the postMuenster Anabaptism movement and his stand on a "strict avoidance" for those excommunicated. After describing the "Meidung Controversy" as it continued through the seventeenth century, the reader arrives at Bachman's lengthy and well-detailed accounting of the “The Amish Division” followed by a final chapter on “The Amish in America.”

These 60 pages are as informative today as they would have been for the reader seeking a short history of the Amish 75 years ago. His evidence is grounded in citations to many scholarly works on Amish and Mennonite history and historical figures and the movement of Anabaptists to America, including C. H. Smith's Mennonites of America (1909). Reading Bachman's history chapters, it is plain to see that he was once a giant on whose shoulders Hostetler stood and who Hostetler acknowledged but is now in the shadows of many others who have also written more recent historical accounts of the Amish and various plain groups. For example, he is cited in neither Nolt's (2015[1992]) A History of the Amish nor in Kraybill, Johnson-Weiner and Nolt's (2013) The Amish.

The remainder of Bachman's book includes 28 chapters (all short in length), with each centered on various religious, cultural, or social dimensions of the Amish. None of the chapters are actually numbered. For the purposes of this review, I have divided these chapters into three 
primary foci (perhaps "chapter clusters" is the better phrase): an introduction to the Amish in America at the time Bachman lived in Lancaster County, the Amish church, and the Amish community.

Bachman introduces the Amish through a series of five chapters that largely describe their outer or external characteristics, all of which are likely familiar to readers of this review, and all of which are essentially covered (like the history chapters) in subsequent books about Amish society and culture. For example, Bachman emphasizes the rural character of the Amish (see chapter titled “A Rural People”). This chapter is essentially about social change, as he subtly contrasts the Amish preference for living in rural settings with some of the more progressive Mennonites groups in the Lancaster area who have drifted out of farming and into a more urban and modern (technologically) lifestyle. He foreshadows the present day situation of the Amish, with the rapid growth of settlements (Donnermeyer and Luthy 2013) when he observes:

One need not look very far into the recent movements of Amish to other places before he discovers that a very real cause of the migration was the pressure of population, which is recognized as every old explanation of migrating groups. (p. 69)

The next chapter is about “Amish Homes,” described in meticulous detail. Much of this chapter is devoted to which material objects are allowed and not allowed in an Amish home. This chapter has not a single citation, but none are needed because it is based on Bachman's quartercentury experience living and preaching in the Amish-occupied parts of Lancaster County. Likewise, the chapter about "Amish Farmers" contains few references but observations that must be based on Bachman's personal knowledge. This chapter, more than any other in Bachman's book, describes the Amish in much the same way as the contemporary work of Kollmorgen (reviewed next). It emphasizes the relationship of the value of farming with restrictions on formal education beyond the eighth grade, debates about acceptable farm technologies, and resistance to government programs associated with agriculture. He mentions what today we would call "workarounds” (Ems 2014). For example, Bachman states on page 82: "It may, however, be possible that a non-Amish farmer who owns a tractor will come to his Amish neighbor's aid and plow for him..."

The chapter titled “Amish Apparel” can be read in two different ways. Its description of clothing indicates the extent to which apparel has not changed, yet, it mentions on p. 94 the development of “...certain concerns to supply readymade Amish garb...” In several places of this chapter, connections between clothing and New Testament passages are made.

We find in “Amish Travel” another chapter without a citation, but again, Bachman’s personal knowledge is the source. Like the chapter about "A Rural People," this chapter is about change, this time on generational differences between preferences for buggy technologies. Bachman is also forthright in stating that although they forbid the ownership of a motor vehicle, “...the Amish do not hesitate to hire automobiles and a bus to take them [places]” (p. 103). Another workaround! Rather ominously, Bachman concludes this chapter by assuming that one 
day the "...restriction concerning automobiles..." will be “...lifted, which when it occurs, will be after a terrific struggle in the church...” (p. 111).

The second cluster of chapters, nine in total, focus on the Amish church, from church leadership to death and cemeteries. Again, each of these chapters demonstrate Bachman's extensive knowledge of the Amish in the Lancaster County area. They are wonderfully detailed accounts with few citations, because he does not need them. The chapter on "Church Organization" includes the articles of agreement from a conference held in 1809 at which ministers reached consensus about rules “...to the order and laws of the church” (p. 118). He mentions this after describing the Amish as having “...no central organization...” (p. 118). Following this chapter are chapters on "Services of Worship," "The Lord's Supper," and "Admission to the Church." In particular, the chapter describing communion has a richness of detail not found in contemporary accounts. Like so many other scholars of the Amish, including Smith, Bachman emphasizes that the role of "Church Discipline," confession, and the Meidung is “...not only to keep the church pure, but also to reclaim those who are in error” (p. 151). The brief chapter about "Interests Beyond the Local Congregation" is focused on fellowship between various Amish church groups and the ability of ordained leaders to "...take part in the services of other Old Order churches” (p. 164).

The remaining three chapters focus on “Amish Weddings," “Amish Funerals,” and “Cemeteries.” These chapters, as with nearly every other chapter, are nicely detailed descriptions that have great relevance to any reader today because so many of the Amish cultural and religious practices have not changed much, or the extent of change can be discovered by comparing the present with the past as depicted by Bachman. Hence, what was relevant 80 years ago is relevant today, and likely well into the $21^{\text {st }}$ century.

The final cluster of chapters loosely possesses a theme around the concept of community. "The Amish and Education" reminds readers that the sixteenth century founders of the Anabaptist were "men of learning” but who "...themselves believed that no course of training was necessary to be called to preach the Gospel” (p. 199). This establishes the historical basis for present-day patterns of eighth grade education, a focus on vocational skills, and controversies with governmental requirements. Next comes “The Amish and the State," a titled used later in Kraybill (1993), even though no reference is made back to Bachman's original use. Bachman describes patterns of voting, jury service, and military service—or lack thereof—at the time.

The next chapter-”Special Days”-turns the reader's attention to holidays, but the emphasis here is as much on what is not observed as what is observed. Bachman does a great service to readers by describing many special days in U.S. society as “...unknown among the Amish” (p. 216). Christmas is observed as a religious or holy day, as is second Christmas. This "second day" pattern is likewise the case for other holidays, which allows Easter Monday and Whitmonday (day after Pentecost) to be a time of visiting, and hence, enabling the Amish “...to keep the Festival Days in a religious sense...” (p. 217). 
"Music among the Amish" describes prohibitions on instruments, radios, record players etc., whilst emphasizing a capella singing in German of songs from the Ausbund. He reminds readers that the Ausbund “...is likely the oldest hymn book in use by any Protestant church” (p. 224), which has been “...handed down from generation to generation” (p. 225).

The chapter on “Amish Youth” begins with a rich rendition of Sunday sings, but within the context that young people are restricted in what they can attend or participate in beyond their own community. The focus shifts to adults in the next chapter, "Woman's Place among the Amish.” Taking note that the husband is indeed the head of the household, he describes the location of Amish women and their important roles in the home-lending support to Reschly and Jellison’s (1993) Great Depression-era findings — and as having “equal rights with the brethren when it comes to congregational meetings” (p. 240). Following this is a chapter that touches on a unique topic, that is, one to which subsequent books about the Amish devote little or no attention. It is the "Care for Dependent Children," by which Bachman means orphans and children of widowed parents and their remarriage. The next chapter turns its attention to the "Provision for Old Age." The emphasis here is on how aging parents pass on the house and farm—but with a "life right provision" so that they do not have to move.

A shift in focus to "Relief of Poverty" centers first on early Anabaptist writings that interpret the community of goods as described in the Acts of the Apostles as about "compassion" and "charity" for the poor. He then proceeds to describe the role of the deacon in dispersing funds when necessary and justified. "Mutual Aid" has a similar organization. First, the Anabaptist interpretation of loans and related interest payments is discussed, followed by present-day practices of Amish loaning money so that young families can get a start in farming or some other economic venture. Bachman also mentions cases of Amish men who are "[...] thrown back through illness or accident, that the Amish set a day [...] and join hands in bringing their neighbor's work up with the remainder of the neighborhood” (p. 263). As well, Bachman describes barn raisings and mutual fire insurance, emphasizing throughout a "neighborly spirit and helpfulness” (p. 266).

Like Smith, as reviewed earlier in this essay, Bachman devotes some attention to "Bundling.” Unlike so many other chapters in the Bachman book, this one contains many citations. Bachman arrives at the same conclusion as Smith. For example, Bachman exclaims, after noting that this is one thing outsiders claim to know about the Amish, that: "To what extent the custom continues to the present day is [...] difficult to learn.” He concludes with three important points: (1) it was a widespread custom in earlier days for many European-based groups in America, including the Amish: (2) some Amish still engage in the practice; and (3) it is “definitely” opposed by the Amish church.

Another chapter generally not covered in recent tomes is "Superstitions." Bachman gets right to the point in this chapter, namely, “...the Old Order Amish are no more superstitious than 
their non-Amish neighbors” (p. 275). From there, he describes the practice of pow-wowing, hex signs, and beliefs about photographs.

"Schisms" focuses on brief accounts of the development of the Church Amish, Peachey Church, the King people, and the Stoltzfus people, to use Bachman's labels. ${ }^{11}$ In this chapter, his goal is to describe the general differences in lifestyles and technology use amongst these groups, and of their interpretation of the strictness of Meidung.

The title of the final chapter, "Our Kind of People”, would appear to be a way to wrap-up or tie together all previous chapters. However, it is not. Similar to Smith, this book has no real summary and conclusions. Instead, this chapter examines Amish perceptions, emphasizing that the Amish feel neither inferior about themselves nor do they feel superior to the non-Amish. He states, "The Amish do not like the publicity which their lives have been receiving” (p. 292). I wonder what Bachman would have to say about this subject if he was writing about the Amish in this century?

Each of the 14 chapters in this third cluster (the Amish community) is worthy of careful reading because each subtly describes how the Amish were changing and how they have established an effective social organization and related cultural practices for coping with change. Plus, there is the added advantage that readers who pick up this book today can compare what they know with the portrait of the Amish Bachman so carefully created over 75 years ago. This is likewise true of the other two chapter clusters and the first set of chapters on the historical development of the Amish. In style, Bachman's book is very different from his contemporary, Walter Kollmorgen, which is reviewed next. However, together, they form a tandem of work (shall we say, the right shoulder and the left shoulder) of all subsequent scholarship about the Amish. As well, it could be argued that Bachman's book and the next reviewed work by Kollmorgen are the first two truly social scientific accounts of the Amish. Hence, what we should be celebrating is a diamond anniversary, not a golden anniversary!

\section{The Amish as a Community: The Work of Walter Kollmorgen (1907-2008)}

Seventy-five years later, contemporary readers can still find much relevance in Kollmorgen’s 1942 report The Old Order Amish of Lancaster County, Pennsylvania, as Lutz (2017) demonstrates in this issue. Indeed, it is a splendid and detailed scholarly account of the Amish in Lancaster County prior to 1940, when the actual field work was conducted. Its historical value is large, but there is far more value in what it can teach us about contemporary scholarship of the Amish and of other plain Anabaptist groups.

First, however, some background is necessary. Kollmorgen's work was “\#4” in the Rural Life Studies series published through the U.S. Department of Agriculture, Bureau of Agricultural Economics. Each report begins with the same title: Culture of a Contemporary Rural Community. Kollmorgen's academic background is geography, and it is from this perspective that he approached his study of the Amish. His examination is a detailed analysis, using empirical 
data whenever and wherever it could be found, of the Amish community in Lancaster County. Yet, despite the dense analysis of farm land values, commodity prices, average farm size and a plethora of other numerical particulars, its real value is the conceptual context of the study itself. There were five other community level studies in this series, with each site selected and studied, according to the forward that was written by Carl C. Taylor, a pioneer in the development of rural sociology and rural studies more generally, to be examined “...contemporaneously by six different participant observers or field workers...”. The communities ranged:

...on a continuum from high community stability to great instability. At one end of the continuum, an Amish community in Lancaster County, Penn., was selected. At the other end, a 'Dust Bowl' community in Kansas was chosen. The other four communities range themselves between these extremes. (Foreward)

Even though each study was independent and formed an interesting ethnography in its own right, the comparative nature of Kollmorgen's and the others' work in this series is unprecedented, revealing drawbacks to the contemporary Amish literature, notably its near disregard for theory. ${ }^{12}$ Of special note is that Charles Loomis, whose work is reviewed next, helped collect data for Kollmorgen's study (Loomis 1979) and was involved in authoring one of the other case studies.

Kollmorgen's work reflects the style of sociological studies of American communities from the first half of the twentieth century. For example, the minutiae of his statistical data and the ponderous results narrative will be difficult to follow for those impatient readers of today raised on wifi and the web. Yet, it was typical for the time. The long procession of community studies with this style of detailed analyses includes the original Lynd and Lynd (1929) community study and their follow-up work (1937) on Middetown; Hollingshead's (1949) investigation of the youth in the small community of Elmstown; and Hunter's (1953) analysis of inequality, power, and decision-making within a large city in the South. All were hallmarks of the sociological enterprise at that time.

Beyond its contextualization within a series of theoretically sampled study sites based on levels of stability, two sets of generalizations mark Kollmorgen's work and justify why his scholarship should be re-read and re-recognized. One cannot but wonder how much his work informed Hostetler and how much Hostetler's original edition of Amish Society would not be recognized for its superb scholarship today if he had not borrowed extensively from the earlier insights of Kollmorgen.

The first set of generalizations concern his introductory description of the Amish. Despite Kollmorgen's extensive use of census data and statistical tables, he begins his Rural Life study with a section titled simply "Identification and Characterization of the Community." In this section, he articulates three principles by which the Amish live. They may seem obvious today, having been described in one variation or another in nearly every scholarly treatment since, but given the time he conducted his research, his insights are ground-breaking. Each in itself may not 
be original (in fact, his careful footnoting cites the original sources of these principles), but restating each in a short, collective narrative that spans less than two dozen pages makes it a remarkable piece of scholarly advancement.

The first is noncomformity. To quote:

It is a remarkable fact that the nonconformity practices of the Old Order Amish, which differentiate them sharply from other people, have been maintained for centuries and are still being maintained in a compact agricultural-industrial area. (p. 5)

Embedded in this excerpt is the assumption that nonconformity is persistent in the face of economic and social change. Indeed, it is a contemporary characteristic of the Amish, with a heritage extending back to the Protestant Reformation's beginning. Change is present, but persistence is usually stronger. The second principle is separation, which Kollmorgen describes as "...obligatory in everything in which standards of the world conflict with standards of the gospel and is maintained particularly with reference to amusements, dress, personal appointments, and home and farm conveniences” (p. 8). Following closely is his description of the principle of avoidance of organizations, that is, of being "unequally yoked together with unbelievers." To this he adds:

For the sake of maintaining uniformity in observing separation from the world, avoiding the unequal yoke and maintaining other church practices, the Old Order Amish have adopted church disciplines which [...] regulate in considerable detail the lives and activities of all members. (p. 9)

These three principles are a cogent description of sustainability in Amish society that has great relevance for understanding their religious, cultural, and societal features even today. But along with persistence is change. Even though less explicitly stated, change is woven into every paragraph of every page of Kollmorgen's work and forms a second and significant set of generalizations about the Amish of which future scholars should remain mindful. He describes the succession of peoples who lived and continue to reside in Lancaster County, from the Indians through the Scotch-Irish, Lutheran, German Reformed, and Mennonites and Amish. He reviews changes in crops grown, the ups (mostly) and downs of land prices, variations in farm operation size, and other trends forming the evolving economic base on which their stability depends. He observes that "A loss of financial independence may well be accompanied by a loss of other forms of independence” (p. 12). In Europe, the principle of separation was "bilateral” while in North America it is "unilateral”; hence, "the Old Order communities [...] disassociate themselves sharply” (p. 21).

Kollmorgen devotes a considerable portion of his monograph to how urbanization and industrialization in Lancaster County is affecting the Amish, from crop varieties to the impact of paved roads. Pages 79 through 82 describe problems associated with car ownership, alcohol, theft, and other issues, observing that the "high degree of regimentation" in church discipline "results in numerous taboos that set the stage for many of the problems of youth" (p. 79). He 
mentions, albeit briefly, divisions within the Amish and the roots of these schisms in the changing prescriptions and proscriptions found in the diversity of disciplines between Amish church groups.

In the final section of his monograph, Kollmorgen considers the future of the Amish within the context of a continuously changing America. He points out that the Amish practice "strategic retreats" (p. 102) from prohibitions established by church disciplines of the past as a way to cope with this change and maintain the principle of separation. Yet, he is pessimistic about the future of the Old Order Amish. Even though he does NOT predict their demise, he worries about the continued use of the Pennsylvania Dutch language, of maintaining the principle of the unequal yoke in the face of widespread development of farm cooperatives and other organizations, of the diminished divide between urban and rural lifestyles and economies, and of the presence of more "liberal Church-Amish" who provide alternative membership options for those who find the Old Order church discipline too prohibitive.

Walter Kollmorgen went on to a distinguished career at the University of Kansas, and a very long life. He was appointed Chair of the Department of Geography in 1947. According to a history of the department: “Under Kollmorgen’s leadership and example, geography at KU was soon transformed from an appendage of geology into an active academic department with a high national reputation” (Dept. of Geography and Atmospheric Science).

Kollmorgen’s “\#4” in the Rural Life Studies was a ground-breaking piece of Amish scholarship. Scholars today may not perceive a direct link between their own work and Kollmorgen's, but it is there. Others at the time used Kollmorgen's study and data for their own scholarship, either within Amish studies (Getz 1946) or in rural sociology and sociology (Burgess and Locke 1945; Nimkoff 1947 and Gillin 1948). Of the two outstanding monographs about the Amish at this time, Kollmorgen's scholarship more so than Bachman's influenced other scholars.

\section{The Amish as a Social System: The Work of Charles Loomis (1905-1995)}

Charles Loomis was President of the both the Rural Sociological Society (1947-48) and the American Sociological Association (1967). He first worked for the U.S. Department of Agriculture as a social scientist and moved on to the department of sociology at Michigan State University, where he was the head of the department for 14 years (American Sociological Association, accessed October 10, 2016). Loomis was not only involved in collecting data for Kollmorgen's study; he was also co-author with Olen Leonard (1941) of another Rural Life Study, El Cerrito, New Mexico, which was “\#1” in the series.

For many decades, Loomis was a prominent social scientist who wrote from a functionalist perspective, that is, his approach was to view society at large and various subcultures, groups, and human institutions within as a type of system that could be dissected into their elemental properties. 
Though he often mentioned the Amish as an illustration, Loomis focused most intensively on the Amish in his 1960 book Social Systems: Essays on Their Persistence and Change. His first essay describes in tedious detail an array of sociological concepts about the general elements and elemental processes by which any society or subculture operates. By element, Loomis (1960) meant "simply one of the constituent parts of some larger whole" (p. 5). These include beliefs, sentiments or feeling, goals, norms, status-role (i.e. position individuals occupy within a system), rank (i.e. hierarchy), power, sanction (i.e. rewards and punishments), and facility (i.e. means to attain goals). Parallel to these elements are elemental processes, which Loomis defines as both the persistence of and changes in the way each of the elements relate to each other. Hence, he uses verbs instead of nouns to describe processes associated with each element, such as knowing (beliefs), feeling (sentiments), achieving (goals), standardizing (norms), dividing (status-role), ranking (rank), controlling (power), sanctioning (sanction) and facilitating (facility):

[...] each process is characterized by a constant quality of regular and uniform sequences and is distinguishable by virtue of its orderliness. This same orderliness is the essence of any social process through which transition from one social condition to another is accomplished. (Loomis 1960, p. 6)

Loomis wrote during a time in the history of sociology when functionalism was the dominant theory. Subsequently, functionalism was heavily criticized for its near obsession with stability and order, and its disregard for divisions and inequalities within a society, as well as for an evolutionary view of change rather than an approach that could also account for rapid, abrupt, and oftentimes disruptive change (Ritzer and Stepnisky 2013; Powers 2010). Nonetheless, Loomis' approach is a helpful way to dissect the Amish system into its various elements and processes. From his analysis, many valuable insights can be found about Amish life and Amish relationships with the non-Amish.

Perhaps the prime reason Loomis was attracted to the Amish within a book of essays focused on a systems approach to society is his depiction of them as a "slowly changing social system that may illuminate the basic elements and processes that compose social systems and make them work as systems” (p. 213). Hence, these nine characteristics (elements and elemental processes) of a social system form a great deal of the organization for his discussion. For example, belief (knowing) is used to delineate "strict adherence" to the Bible and the centrality of the Martyrs' Mirror to Amish religious life. "Reverence" is the trait associated most with sentiment (feeling). Reverence is found in rites of passage (e.g. baptism and weddings). The "communication of sentiment" (p. 219) is through visiting and working bees, "rites of intensification" that illustrate their Gemeinschaft culture. "Full fellowship" through participation in and conformity to the church is central to the goal (achieving) of salvation. Conformity to the church rules are norms (standardizing) that symbolize an "unequal yoke" to the world. It is here that he cites the typology of another prominent functionalist, Robert Merton (1949). In this typology, Merton discusses five primary modes of adaptation to "ends" and "norms": conformity, innovation, ritualism, retreatism, and rebellion. Both conformity (remaining in fellowship) and 
retreatism (shifting to a non-Amish church, such as conservative Mennonite) are emphasized. In addition, Loomis discusses Merton's use of retreatism, however briefly, to illustrate norms (standardizing) at both the level of an individual Amish person, and, more collectively, of Amish groups who have relocated to more remote areas.

Loomis continues by using status-roles (dividing) to discuss gendered differences in the family and of ordained men (bishop / minster / deacon). He mentions that there are 33 districts in Lancaster County, PA, with a bishop for every two church districts. Rank (ranking) is used to emphasize the smaller social distances among the Amish than among mainstream Americans, but stating that hierarchies do exist. Farming, for example, is given a "high evaluation" as the preferred occupation for males, and also "age and wisdom are assumed to be related” (p. 226). The nomination and selection of church leaders is described as well under this element. The discussion of power (controlling) is centered on the role of the church deacon to initiate the discipline of church members who do not conform. Sanction (sanctioning) is illustrated through the Meidung and the case of a "David Sussfuss" who subsequently joined a "Church Amish" group (pp. 230-31). It is not mentioned by Loomis as to whether this is the real name of an individual or a pseudonym, and a citation to the source of his information about this case is lacking. Finally, the element and elemental process of facility (facilitating) is highlighted by the limited use of technology and avoidance of a "preoccupation” with things (p. 232).

In addition to elements and elemental processes, Loomis’ social systems approach includes a third set of concepts, “comprehensive or master processes,” defined as one of six processes activating "many or all of the elements” (p. 7):

1. Communication. Loomis places great importance on the "bi-lingual and sometimes trilingual ability of the Amish” (p. 233) to access information from the outside world via newspapers / other sources and to conduct business, all the while maintaining internal cohesion.

2. Boundary maintenance. This master process is associated with the cultural and spatial dimensions of identity, that is, identity as “God's peculiar people” (p. 234) and nonconformity to the outside world. For example, farming and a horse-and-buggy lifestyle serve the same function, as spatial boundary maintenance. Loomis' use of "boundary maintenance" is the first in Amish studies, although it is unclear whether later authors can credit his introduction or newer importations.

3. Institutionalization. Here, Loomis refers to the heritage of church formation and martyrdom over their 400+ year history, beginning with the Protestant Reformation.

4. Systemic linkage. This refers to connections between a group of people and others. Loomis describes how the Amish conform to various local, state, and national governmental regulations associated with participation in a market economy-purchasing farm inputs and selling agricultural products, paying taxes, struggling with compulsory education, and voting against local initiatives to consolidate schools.

5. Socialization. Here, Loomis focuses on the role of the family.

6. Social control. For reasons unknown, Loomis does not apply social control as a process that 
activates more than one element/elemental process in his essay. Instead, he shifts to a discussion of the fourth and final dimension of his model for social systems. These are the "conditions of social action" that include territoriality, size, and time. He uses only territoriality (i.e. space), ignoring both time and size, the latter defined as the number of subgroups in a society rather than the number of people. Perhaps the reason that the final master process was skipped is because the essay ends with an example of "successful systemic linkage” involving a division among the house Amish that created another variation on the more progressive church Amish (pp. 243-46). It is a story about how social change seeps and creeps into any group, no matter how insular and separated. This story concludes Loomis’ essay.

Remarkably, despite his regimented but thorough analysis, no section summarizes or wraps up his main points, in pattern with Smith and Bachman, apparently part of the social science style at the time. Altogether, Loomis refers to the four dimensions of element, elemental processes, master processes, and conditions of social action as the "Processually Articulated Structural Model,” providing a summary figure of the concepts on page 8. Even though the PASM model may strike some as mere academic jargon, Loomis' analysis of the Amish was, for back then — and today yet! — one of the few serious attempts to describe the Amish based on an explicit theoretical approach. Perhaps only Werner Enninger's work matches the theoretical sophistication of Loomis' approach (Anderson 2017b). Whatever shortcomings the PASM model may have from a twenty-first century perspective, it was a sincere effort to describe the Amish within a framework by which they could be compared to other societies and subcultures. In this sense, the value of Loomis' work is the same as Kollmorgen's, namely, the value of theory, a rare commodity among contemporary writings about the Amish.

\section{“Amishland” and Old World German Peasantry: William Schreiber (1906- 1995)}

William I. Schreiber was a long-time professor of German at the College of Wooster (1937-75) when he wrote Our Amish Neighbors (with illustrations by Sybil Gould, who also worked at the College of Wooster). In the acknowledgements, the twenty-first century reader will find many familiar names representing earlier Amish scholars, including Harold Bender at Goshen College (for making “important suggestions about Mennonite historiography”) and Grant Stoltzfus, at Eastern Mennonite College ("for suggestions leading to deeper insights into the language of the Ausbund"). As well, Schreiber acknowledged the "members of the East Union Amish districts who graciously allowed an outsider to share in their community life” (p. viii).

Not to be glossed over lightly, Schreiber's work was published under the prestigious University of Chicago Press. Kraybill $(2005,46)$ asserts that Elmer Lewis Smith's books fell into the shadows partly because he did not have the auspices of a strong publisher, in contrast to 
Hostetler's work with Johns Hopkins University Press. Schreiber is a counterfactual; even a strong publisher did not cure an author's neglect in the Hostetler era.

Soon after publication in 1962, Our Amish Neighbors was the subject of a somewhat sympathetic but nonetheless curiously critical review in The American Anthropologist by Gertrude Ender Huntington, a well-known collaborator of Hostetler's. ${ }^{13}$ She states that it is “...the first book to be published on the Ohio Amish [which] permits comparison with other Amish settlements such as the well-known one in Pennsylvania” (p. 436). ${ }^{14}$ She describes it as "fairly accurate"_-but_- As the name implies it is a popular book written for 'English' people who live near the Amish and for others who would like to know something [...]” (p. 435). However, she concludes that it has "limited value for anthropologists." She disagrees with his thesis of linking present Amish society and culture back to a German peasant past: "It is written by an outsider who, though sympathetic and interested, has always remained outside” (p. 435). The use of the words "outsiders" and "outside” is hardly a surprise, given her long collaboration with Hostetler, and we see, once again, a consciously constructed divide that hopefully becomes anachronistic and silly from the point of view of future scholars of the Amish and other plain Anabaptist groups.

Schreiber's account focused on Wayne County more than the other counties composing the Greater Holmes County settlement. Wayne County is the location for the College of Wooster and, even today, a greater presence of Amish splinter groups exist there, groups who more strongly resist outside influences and are more conservative than the Old Order. Further, as the title of this section declares, Schreiber refers to the area as "Amishland" and frequently notes the population size and density.

The page before the introductory chapter contains a quote by Goethe: "How very much I have again learned to love that class of people one calls the lowly, but which, God knows, is certainly the highest!” (p. xii). Hence, the Amish-German peasant connection is evident from the beginning to the end of Schreiber's book. For example, on page 7, he exclaims: "To me, a German-born American, the Amish now seem more German than the peasants of my native land.” On page 80, he says: “As a person of European background from original peasant stock, this writer sees a remarkable similarity between the 'Bauer' of western Germany and the Amish of rural Ohio” (Bauer is a German word for farmer.)

The introductory chapter (un-numbered) begins with a clever hook to catch the reader's attention; it describes Schreiber's experience attending an Amish church service. Following quickly is an historical account of the Amish that begins with Amish (and Mennonite) relocation to America and specifically to northeast Ohio. He describes the Anabaptist groups who settled the area, with a list on page 26 that includes a full spectrum based on their relative adoption or rejection of “American cultural patterns.” He reminds the reader that "The Old Order Amish distinguish themselves from the rest of the Mennonites by their definition of the 'world,' not by a difference in confessional doctrines" (p. 31). He concludes Chapter 1 with Amish population data 
from the Greater Holmes County directory, one of the first ever published (1959). When adding the conservative groups that did not want to appear in the directory, he estimates nearly 4,400 Amish in the vicinity. ${ }^{15}$

Most chapters cover the same topics as Bachman and Smith, and, in general, these predecessors provide a more detailed accounting — but not always. Chapter 2 "The Amish Homestead" contains an excellent description of the bank barn on (pp. 47-50), which Schreiber points out is a transplant from Germany. In this same chapter, he deals with Amish views and socialization of children, the role of women, and varieties of plain clothing. He mentions that one of the Amish parochial schools has "its own horse-drawn 'school bus', as the children call it affectionately” (p. 55). On page 70, he concurs with Bachman's observation that the Amish are not concerned with changing fashion.

Chapter 3 "The Old Order, Amish Way of Life" begins by linking Amish society and culture to the Schleitheim and Dortrecht Confessions of Faith. By far, the most valuable section of Chapter 3 is titled "Scriptural Basis." It is derived from a "conversation" that took place between Schreiber and an Amish preacher about 18 years prior to publication of the book (indicating that Schreiber's experiences with the Amish are about as long as Bachman's). From pages 79 through 87, the Biblical basis of Amish cultural practices are described. ${ }^{16}$ One other interesting tidbit is mention of the "Lentus Bus Line" (for local transportation to do business in towns like Wooster), underwritten by several dozen Amish families.

Chapter 4 "Meidung in Modern Times" is devoted exclusively to the case of Andrew Yoder, who filed a lawsuit and court injunction for damages resulting from shunning (or "boycott") directed against him by his former church district. He won the lawsuit and was awarded damages. Even though this chapter is an illuminating description of the case, it is not very good in explaining the Meidung.

Chapter 5 focuses on "Community Life and Organization.” It provides more detail about the Sunday service, the member's meeting prior to twice-a-year communion, the duties of the three types of church leaders, and the Ausbund. Hence, Schreiber equates community life with church life, mentioning nothing beyond the latter. Yet, worthy observations exist, such as statements about church divisions, that the origin of differences “.... are home-grown, that they have originated in the local setting, and that they not been forced upon the group [from the outside]" (p. 133).

Chapter 6 "Amish Life as Revealed in the Sugarcreek Budget" is unique among all books about the Amish, either pre- or post-1963. After a brief history of how The Budget came to include Amish and Mennonite community reports, the chapter describes the column content, from weather to the health of children. The chapter also describes obituaries and verses dedicated to those who have passed away. However, the most interesting and informative part of the chapter is on page 165, which describes reports in the Budget that foreshadow Amish settlement 
growth (Donnermeyer and Luthy 2013) in the twenty-first century. Schreiber states: "The Budget often discusses in its columns the scarcity of land which is plaguing the Amish more and more [...] There is hardly an Amish community that has not experienced the loss of members...” (p. 165).

The final main chapter concerns the future but is titled "Propagation of the Past." This chapter presages part of Stevick’s (2014[2007]) Growing Up Amish. He gives an account of courtship patterns, discusses bundling and links it to the practices of peasants in Switzerland and of disagreements about its practice, describes the Amish wedding, and discusses the Amish preference for a Tuesday or Thursday wedding by linking it to "pre-Christian Germanic gods” (p. 186).

Schreiber's brief afterward describes the Amish as “...the last refuge of the German peasantry” (p. 206). On the final page, he quotes from Goethe's contemporary, Schiller (17591805), whose poem of William Tell stresses that true virtue resides in “...the land, the dear land of the sires” (p. 208). In this short chapter, one can see the skill with which Schreiber wrote Our Amish Neighbors and his nostalgic view that the Amish of his time are connected to the German peasants of times past, with an under-current or tone to his writing that the change that has transformed most of Europe and North America through the advent of the industrial age is not always to the good. Indeed, from this German peasant perspective, we can find a predecessor to Reschly's (2017; 2000) more nuanced and less romanticized contention that the Amish embody a community habitus forged in Europe under conditions that forced them into the landless farming peasantry.

I agree with Huntington that Schreiber's book is a sympathetic, even romanticized, account, and that it is written largely for a non-academic audience. I mostly agree with Huntington that the German peasant-Amish link was taken too far by Schreiber, because by the time Schreiber wrote, the Amish presence in North America was already more than two centuries old, and because their presence in Europe was nearly non-existent by the beginning of the twentieth century, if not decades before. Nonetheless, Schreiber's attempt to emphasize their peasant heritage is unique in scholarship about the Amish, and can provide valuable insights and ways of thinking about any religious sect, especially those that have relocated from one continent or country to another. As well, it is worth noting that many Amish today travel back to Europe to visit historical sites of the Anabaptist movement in Zürich, Muenster, and elsewhere. The Heritage Historical Library in Aylmer, ON, and the Amish and Mennonite Heritage Center in Berlin, $\mathrm{OH}$, are just two of many entities who attempt to preserve and remember what happened in the past, a platform from which contemporary change can be viewed (Waldman 1986). The remarkable two-volume work of Leroy Beachy (2011) is another example that documents how European-peasant roots and early American experiences have and continued to shape Amish society and culture. 
Perhaps because I am a sociologist, I disagree with Huntington's assessment that the book has little value for anthropologists (and by extension, all the other social sciences). Value is gained by how much the reader can learn through consideration of what the author says. The fact that Schreiber did not write Our Amish Neighbors exclusively for an audience of anthropologists is not really a salient consideration. However, the naïve or uncritical reader from before 1963 would be better served by reading Smith, Bachman, Kollmorgen, or Loomis, unless, of course, they seek to learn more about the Amish in northeast Ohio.

Finally, I am an outsider myself. I am Catholic, grew up in a big city environment, and came to Amish studies early in my career at The Ohio State University. My university is gigantic (over 56,000 students on the main campus) when compared to the academic homes of most Amish scholars, and at a scale comparable to the difference in populations between Elizabethtown, PA, and Shanghai, China. I have noticed more than I want to, and experienced more than I prefer, the patterns of parochialism emanating from some Amish scholars. Hence, I chaffed at the insider/outsider reference by Huntington as a desultory remark of little value for judging Schreiber's attempt to help others understand Amish society and culture. But this dichotomy is hardly a single instance; it has been a longstanding value judgment in Amish studies since the beginning and continuing to today (Anderson 2017a). I know one colleague, now well-published about the Amish in various peer-reviewed venues, who was simply told at the beginning of this individual's research that the individual should not get involved because that individual's background was not Anabaptist. The quality of scholarship is indeed affected by the backgrounds of all scholars, including the religion in which they were raised, but it can go both ways. An insider status can either diminish or enhance quality and even sympathy for the subject matter, but so, too, can outsider status. It is the intellectual imagination of the scholar that really counts. Such labels as outsider and out-grouper (and "my people”) are simply not necessary, and even demeaning! To a lesser or greater extent, nearly everyone-Hostetler, Smith, Bachman, Kollmorgen, Loomis and Schreiber-reviewed, discussed, and cited in this review were not Amish when they wrote, and, hence, outsiders.

\section{Conclusion}

We who want to be scholars about the Amish and other plain Anabaptist groups live in challenging times, given the slipshod claims of Amish reality shows, the explosion of romance novels centered on the Amish, and the instantaneous broadcast through every conceivable cable and web-based news outlet when a few Amish break the law, from cutting beards to large parties of Amish young people busted by the police. We should cast aside shadows and stand on the shoulders of Smith, Bachman, Kollmorgen, Loomis, Schreiber-and Hostetler-as equals in stature.

We need to remain factual, even though each of us has a distinctive point of view or perspective for interpreting Amish identity and change. That is why it is well-worth reading about the Amish from work published before 1963, for these works are enlightening and can 
teach us much about how we should conduct ourselves as scholars in the twenty-first century. Their presentations and interpretations of the Amish contain much factual information that is mostly today either forgotten or assumed to be true without citation. Nonetheless, their work is quite useful for historical comparisons.

First, the work of authors like Loomis and Kollmorgen show us the value of consciously approaching the subject matter from a clear framework. Even Schreiber's peasant-Amish link is a useful framework that separates his book from purely descriptive work or work relying on catchy phrases instead of real theory. The conceptual frames may be more or less relevant to a twenty-first century scholar, or may require considerable overhaul to be used today, but, indeed, all three did try to wrap a perspective around the myriad details in their varied approaches to Amish society and culture.

Second, value is to be found in sound data, both the quantitative and qualitative, and as more than just the self-validating anecdotalism of an "insider." Anyone who has ever engaged in data collection, management, and analysis knows how much work this involves. In particular, Kollmorgen and Smith demonstrate for us the value of empirical data and what is today called "number-crunching." As well, Bachman, Schreiber, and Smith, again, show us the value of qualitative data. Qualitative data may take longer to collect (consider how many years of experience and living in an Amish area each of these authors drew upon for their books) but adds warmth to cold facts, giving humanity to the Amish.

Finally, each of these authors are both positive and negative role models for how scholars of the twenty-first century should (ideally) conduct themselves. We should be theory or conceptually driven in our work. We should conduct research that is empirically sound. And, most of all, we should avoid to the extent possible what is now labeled "office politics.",17 Outsider vs. insider status is not relevant if the theory and data are sound and attempt at interpretation sincere. However, I am not so naïve as to believe that the academic version of shunning, refusing to collaborate, and expropriating ideas or even passages and titles from others, will ever go away, even among the relatively small cadre of scholars who examine the Amish and other plain Anabaptists. Yet, we should try mighty hard to do so, especially in a century where public images and knowledge about the Amish is dominated by reality shows, romance novels, and sensationalistic news.

\section{Endnotes}

1 “Letter from Sir Isaac Newton to Robert Hooke.” Historical Society of Pennsylvania (Retrieved 7 August 2016).

${ }^{2}$ From an early play by Johann Wolfgang von Goethe about an adventurer and poet named Götz von Behlichingen, with the play of the same name.

${ }^{3}$ Contact information: Joseph Donnermeyer, School of Environment and Natural Resources, The 
Ohio State University, Columbus, Ohio 43210; donnermeyer.1@gmail.com; 614-582-4710.

${ }^{4}$ In every field of study - both the sciences (natural and social) and the humanities / literature / philosophy - rivalries exist, as do other less than honorable shenanigans. It is important to note cross-referencing because one mischievous way rivalries can be expressed is by citing sources other than the work of one who is considered a competitor. Other methods include the purposive endorsing of alternative scholarship produced by others but not by one's rival, being quite parochial about who is allowed into the inner circles of a network of scholars based on their background (wrong religion, wrong university etc.), attending a session where other scholars share their work and then imitating it (perhaps by hiring someone else to engage in the same research), or chatting with them about "what's new with you" with the causal and disingenuous reply, "I've thought of the same thing." All of these contrivances function to create artificial hierarchies, that is, conditions whereby some scholars believe they are the "king” or "queen" of that proverbial hill and then must maintain that status throughout their careers. As well, these forms of tricky maneuvering or "office politics" can be expressed both at the level of an individual scholar and, more collectively, in a single academic department or center of a college or university.

${ }^{5}$ Other works by Elmer Lewis Smith about the Amish include Smith (1956; 1958a; 1958b; 195960; 1961b; 1961c), Smith and Horst (1958; 1959), and Smith and Stoltzfus (1959).

${ }^{6}$ Nonetheless, I, too, experienced a mild example of the "hear no evil, see no evil..." syndrome that the issue of pre-marital conception seems to evoke. Ten plus years ago, I presented on "A Baker's Dozen Facts about the Amish Population” at a Young Center conference on the Amish. The final, or $13^{\text {th }}$, fact was the rate of pre-marital conception (using a seven-month indicator rather than Smith's eight-month measure of time between the wedding date and the birth of the first child). My interest was to gauge deviance as indicated by youth ignoring values about family and marriage vows. Comparisons were made across three major fellowships in the Greater Holmes County settlement, for which directory data were available. At the end of the presentation, a person in the audience who introduced herself as a nurse said that my presentation was very interesting, but whispered “did you have to mention that last one.” I chuckled under my breath and politely replied that it was important in its own right. I should also note that my percentage for pre-marital conception (about 8\%) is likely similar to Smith's finding of a half century ago and now regret that I did not calculate both 7- and 8-month indicators so that I could have compared directly with Smith’s statistics.

${ }^{7}$ Smith's (1961b) 35-page booklet was titled Bundling among the Amish, with the added words on the front page: "A review of the unique custom practiced in the old world, in early America

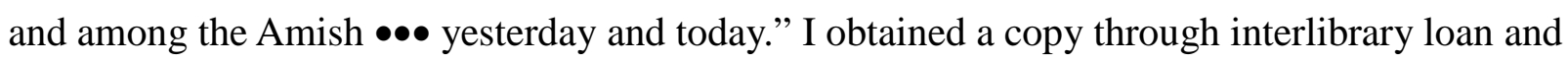
read it. My impression: it is written in the style of a folklorist: froth with detail and with carefully worded conclusions. On page 5, for example, are subsections titled - "Yes-The Amish Bundle," "No-The Amish Don’t Bundle,” and "Maybe-The Amish Bundle.” This is where Smith weighs 
the evidence, going to great lengths to consider its history during colonial days in America and its expression in various parts of the old world, from Germany to Sweden to Wales. He returns to the question of bundling among the Amish on page 24. Claiming the assistance of a young Amish male who argued that bundling still existed, Smith was able to obtain varied statements from Amish in over two dozen settlements from different states. He concludes that bundling does not really exist, but bed courtship does for some Amish, and even that rarely leads to anything considered immoral. After considering the reasons why bundling and bed courtship would be practiced long after it faded away in every other part of American society, Smith concludes: "In a church-centered group such as the Amish, if a concerted effort were made by parents and church leaders, this quaint courtship custom would rapidly fade from the Amish-American countryside" (p. 33). My personal opinion is that Hostetler's campaign against Smith was not what he wrote about or even how he wrote it but mostly that Smith as an outsider was writing about the Amish at the same time that Hostetler, a self-proclaimed insider, was writing about the Amish.

${ }^{8}$ I, too, have noticed this on a few occasions when I teach a session on "Understanding the Amish” in my Introduction to Rural Sociology course. Especially students who have served in the military and returned to the university, or are in ROTC at The Ohio State University, struggle with this aspect of the Amish. Most of these students keep an open mind, but a couple, with scowls and a judgmental tone, condemn the Amish as unpatriotic. My best efforts at a reply have mostly failed to allay their concerns or change their opinions.

${ }^{9}$ The end of The Amish Today includes two appendices. The first is the analysis of Amish surnames. The second is the 1950 Ordnung from the Pike County, OH, Amish community (discussed in Anderson and Anderson 2016, 5-6).

${ }^{10}$ On the inside front cover, the page before Hostetler's introduction to the 1961 re-issuance of Bachman's work, a 1961 date is given for its original publication. In fact, it was published in 1942. Perhaps a rush to re-issue the Bachman study as an "authoritative ethnography” in 1961 accounts for this proofreading error.

${ }^{11}$ All of these groups are today considered Amish-Mennonites from the Beachy movement.

${ }^{12}$ As a graduate student, I read three of the six reports for a sociology of community course: the Amish of Lancaster County, PA; Haskell County, Kansas; and the El Cerrito, New Mexico. Each offers valuable lessons about social change and the sociology of American life.

${ }^{13}$ I did not include Huntington's "Dove at the Window" in this review because it is a dissertation rather than a monograph. I apologize to any who believes this to be a judgment in error on my part.

${ }^{14}$ Curiously, the best contemporary account of the Amish in the Greater Holmes County settlement, by Hurst and McConnell (2010), neither acknowledges Schreiber's book nor cites anything from it. Indeed, more shadows! 
15 The 2015 Ohio Amish Directory for this settlement lists nearly 34,300 Amish. The Swartzentruber groups continue their non-involvement with the directory. There are 20 Swartzentruber church districts in this settlement, according to Raber (2016). Based on my work in estimating the Amish population for the Religious Congregational and Membership Survey, which included counting members and nonmembers (i.e. unbaptized children) of Swartzentruber groups who do participate in directories from other localities, the average size was 152 persons. Hence, $14 * 152=2,128$, and a grand total of about 36,400 Amish in the Greater Holmes County settlement today.

${ }^{16}$ These pages were required reading during the many years I taught "Rural Sociology 5520 Amish Society” at The Ohio State University.

17 “Office politics” are as old as the human race. No scholar, great or otherwise, can escape its clutching embrace. In a style reminiscent of Hostetler's influence on the Pennsylvania German Folklore Society to republish Bachman's work, Newton blind-wrote letters of support for his own work or that were critical of his perceived rivals and had them published under the name of other noted scientists and philosophers of his time who were his friends (Hawking 1998). Goethe was involved for most of a year in developing a set of reforms for the administration of the University of Jena’s bureaucracy (Hatfield 1964).

\section{References}

American Sociological Association. “Charles Price Loomis, October 26, 1905 - July 6, 1995.” Last accessed October 10, 2016 (http://www.asanet.org/about-asa/asa-story/asahistory/past-asa-officers/past-asa-presidents/charles-p-loomis).

Anderson, Cory. 2017a. "Seventy-Five Years of Amish Studies 1942 to 2017: A Critical Review of Scholarship Trends (with an Extensive Bibliography).” Journal of Amish and Plain Anabaptist Studies 5(1):1-65.

Anderson, Cory. 2017b. "The Undistinguished Scholar of the Amish, Werner Enninger, -orHas the Time Yet Come for Rigorous Theory in Amish Studies?” Journal of Amish and Plain Anabaptist Studies 5(2):196-238.

Anderson, Cory, and Jennifer Anderson. 2016. "The Amish Settlement in Honduras 19681978: A (Half) Failed Attempt to Develop an Amish Understanding of Mission.” Journal of Amish and Plain Anabaptist Studies 4(1):1-50. https://doi.org/10.18061/1811/78020

Bachman, Calvin. 1942. The Old Order Amish of Lancaster County. Lancaster, PA: Pennsylvania German Society. Volume 60. Reissued 1961.

Beachy, Leroy. 2011. Unser Leit: The Story of the Amish. Millersburg, OH: Goodly Heritage Books. 
Bronner, Simon. 2004. "Plain Folk and Folk Society: John A. Hostetler's Legacy of the Little Community.” Pp. 56-97 in Writing the Amish: The Words of John Hostetler, edited by David Weaver-Zercher. University Park, PA: The Pennsylvania State University Press.

Burgess, Ernest, and Harvey Locke. 1945. The Family. New York, NY: American Book Company.

Department of Geography and Atmospheric Science. “Department History.” Accessed October 7, 2016 (https://geog.ku.edu/history).

Donnermeyer, Joseph, and David Luthy. 2013. “Amish Settlements across North America: 2013.” Journal of Amish and Plain Anabaptist Studies 1(2):107-29. https://doi.org/10.18061/1811/57700

Ems, Lindsay. 2014. "Amish Workarounds: Toward a Dynamic, Contextualized View of Technology Use.” Journal of Amish and Plain Anabaptist Studies 2(1):42-58. https://doi.org/10.18061/1811/59690

Getz, Jane. 1946. “The Economic Organization and Practices of the Old Order Amish of Lancaster County, Pennsylvania.” Mennonite Quarterly Review 20(1\&2):53-80 \& 98-127.

Gillin, John. 1948. The Ways of Men. New York, NY: Appleton-Century Co.

Guide to the Elmer Lewis Smith Collection, Undated (Twentieth Century). Harrisonburg, VA: Special Collections, Carrier Library, James Madison University. Accessed October 14, 2016 (http://ead.lib.virginia.edu/vivaxtf/view?docId=jmu/vihart00122.xml).

Hatfield, Henry. 1964. Goethe: A Critical Introduction. Cambridge, MA: Harvard University Press. https://doi.org/10.4159/harvard.9780674183278

Hawking, Stephen. 1998. A Brief History of Time: The Updated and Expanded Tenth Anniversary Edition. New York, NY: Bantam Books.

Hollingshead, August. 1949. Elmstown's Youth: The Impact of Social Class on Adolescents. New York, NY: John Wiley \& Sons.

Hostetler, John. 1951. Annotated Bibliography of the Amish. Scottdale, PA: Herald Press.

Hostetler, John. 1952. Amish Life. Scottdale, PA: Herald Press.

Hostetler, John. 1963. Amish Society. Baltimore, MD: Johns Hopkins University Press.

Hostetler, John. 1993. Amish Society (4 ${ }^{\text {th }}$ ed.). Baltimore, MD: Johns Hopkins University Press.

Hunter, Floyd. 1953. Community Power Structure: A Study of Decision Makers. Chapel Hill, NC: University of North Carolina Press.

Huntington, Gertrude Enders. 1963. "Review of Our Amish Neighbors, William I. Schreiber.” American Anthropologist 65(2):435-36. https://doi.org/10.1525/aa.1963.65.2.02a00400 
Hurst, Charles, and David McConnell. 2010. An Amish Paradox: Diversity and Change in the World's Largest Amish Community. Baltimore, MD: Johns Hopkins University Press.

Kollmorgen, Walter. 1942. Culture of a Contemporary Rural Community: The Old Order Amish of Lancaster County, Pennsylvania. Washington, D.C.: Bureau of Agricultural Economics, U.S. Department of Agriculture.

Kraybill, Donald, Karen Johnson-Weiner, and Steven Nolt. 2013. The Amish. Baltimore, MD: Johns Hopkins University Press.

Kraybill, Donald. 2005. “The Redemptive Community: An Island of Sanity and Silence.” Pp. 36-55 in Writing the Amish: The Worlds of John A. Hostetler, edited by David WeaverZercher. University Park, PA: Pennsylvania State University Press.

Kraybill, Donald (ed.). 1993. The Amish and the State. Baltimore, MD: Johns Hopkins University Press.

Loomis, Charles. 1960. Social Systems: Essays on Their Persistence and Change. Princeton, NJ: D. Van Nostrand Company.

Loomis, Charles. 1979. “A Farmhand’s Diary.” Mennonite Quarterly Review 53(3):235-56.

Lutz, Martin. 2017. "Explaining Anabaptist Persistence in the Market Economy: Past Paradigms and New Institutional Economics Theory.” Journal of Amish and Plain Anabaptist Studies 5(2):239-57.

Lynd, Robert, and Helen Merrill Lynd. 1929. Middletown: A Study in American Culture. New York, NY: Harcourt, Brace, and World.

Lynd, Robert, and Helen Merrill Lynd. 1937. Middletown in Transition: A Study in Cultural Conflicts. New York, NY: Harcourt, Brace, and Company.

Merton, Robert. 1949. Social Theory and Social Structure. Glencoe, IL: Free Press of Glencoe.

Nimkoff, Meyer. 1947. “Ethnic Variations in American Family Life.” Pp. 240-55 in Marriage and the Family. Boston, MA: Houghton Mifflin.

Nolt, Steven. 2015[1992]. A History of the Amish. New York, NY: Good Books.

Pennsylvania German Society. Wikipedia: The Free Encyclopedia. Accessed 10/3/2016 (https://en.wikipedia.org/wiki/Pennsylvania_German_Society).

Powers, Charles. 2010. Making Sense of Social Theory: A Practical Introduction. Lanham, MA: Rowman \& Littlefield Publishers.

Raber, Aden. 2016. The New American Almanac. Baltic, OH: Aden B. Raber.

Reschly, Steven. 2000. The Amish on the Iowa Prairie: 1840-1910. Baltimore, MD: Johns Hopkins University Press. 
Reschly, Steven. 2017. "Paradigmatic Paradigm Problems: Theory Issues in Amish Studies." Journal of Amish and Plain Anabaptist Studies 5(1):66-81.

Reschly, Steven, and Katherine Jellison. 1993. "Production Patterns, Consumption Strategies, and Gender Relations in Amish and Non-Amish Farm Households in Lancaster County, Pennsylvania 1935-1936.” Agricultural History 67(2):134-62.

Ritzer, George, and Jeffery Stepnisky. 2013. Sociological Theory ( $9^{\text {th }}$ ed.). New York, NY: McGraw-Hill.

Schreiber, William. 1962. Our Amish Neighbors. Chicago, IL: University of Chicago Press.

Smith, C. Henry. 1909. The Mennonites of America. Goshen, IN: C. Henry Smith.

Smith, Elmer Lewis. 1956. A Study of Acculturation in an Amish Community. Dissertation in Sociology. Syracuse, NY: Syracuse University.

Smith, Elmer Lewis. 1958a. The Amish People, Seventeenth-Century Tradition in Modern America: A Complete, Illustrated Story of the "Old Order" Sect of Southeastern Pennsylvania. New York, NY: Exposition Press.

Smith, Elmer Lewis. 1958b. "Personality Differences between Amish and Non-Amish Children.” Rural Sociology 23(4):371-76.

Smith, Elmer Lewis, and Melvin Horst. 1958. Highlights of Amish Life. Akron, PA: Applied Arts.

Smith, Elmer Lewis, and Melvin Horst. 1959. Among the Amish. Akron, PA: Applied Arts.

Smith, Elmer Lewis, and Grant Stoltzfus. 1959. “The Community Barn Raising.” The Historical Review of Berks County 24(2).

Smith, Elmer Lewis. 1959-60. “Christmas among the Amish.” The Historical Review of Berks County 25(1).

Smith, Elmer Lewis. 1960. "Studies in Amish Demography.” Harrisonburg, VA: The Research Council, Eastern Mennonite College.

Smith, Elmer Lewis. 1961a. The Amish Today: An Analysis of Their Beliefs, Behavior, and Contemporary Problems. Allentown, PA: The Pennsylvania German Folklore Society.

Smith, Elmer Lewis. 1961b. Bundling among the Amish. Akron, PA: Applied Arts.

Smith, Elmer Lewis. 1961c. “The Amish Wedding.” The Historical Review of Berks County 26(5).

Stevick, Richard. 2014[2007]. Growing Up Amish: The Rumspringa Years (2 ${ }^{\text {nd }}$ edition). Baltimore, MD: Johns Hopkins University Press.

Waldman, Marilyn Robinson. 1986. “Tradition as a Modality of Change: Islamic Experiences.” History of Religions 25(May):319-40. 
Weaver-Zercher, David. 2005a. “An Uneasy Calling: John A. Hostetler and the Work of Cultural Mediation.” Pp. 98-149 in Writing the Amish: The Words of John Hostetler, edited by David Weaver-Zercher. University Park, PA: Pennsylvania State University Press.

Weaver-Zercher, David (ed.). 2005b. Writing the Amish: The Words of John A. Hostetler. University Park, PA: Pennsylvania State University Press. 